\title{
AFLP Markers for Genetic Diversity Evaluation of Pomegranate (Punica granatum L.) in Duhok Province, Kurdistan Region - Iraq
}

\author{
Dalal Y. Khudhur SINJARE* and Jaladet M. S. JUBRAEL \\ Scientific Research Center, College of Science, University of Duhok, Iraq \\ *corresponding author: dalal.yousif@uod.ac \\ BulletinUASVM Horticulture 77(2) / 2020 \\ Print ISSN 1843-5254, Electronic ISSN 1843-5394 \\ DOI:10.15835/buasvmcn-hort: 2020.0055
}

\begin{abstract}
In this work, 15 pomegranate (Punica granatum L.) cultivars collected throughout Duhok Province in Kurdistan-Iraq were characterized using ten AFLP primer combinations. A high degree of genetic diversity was found among tested cultivars. The total scored number of amplified fragments was 435 of which 374 were polymorphic. The rate of polymorphism varied ranging 40 to $100 \%$ with an average percentage of 86.64 . The UPGMA clustering analysis based on these data revealed three main groups and that cultivars were not grouped by their geographical distribution. All calculated genetic parameters including PIC, RP, EMR and MI mean results were $0.2974,45.66,22.79$ and 6.872 respectively, further revealed that pomegranate varieties/cultivars in this region have a rich genetic diversity. The findings showed that a molecular characterization was necessary in order to have a reliable result to evaluate and determine relationships between pomegranate genotypes.
\end{abstract}

Keywords: AFLP, genetic diversity, pomegranate (Punica granatum L.)

\section{Introduction}

Pomegranate (Punica granatum L.) is considered one of the oldest known edible fruits, as an ornamental plant, it has been popular in the Mediterranean for hundreds of years (Vazifeshenas et al., 2009). It is also known to be an ancient medicinal crop of considerable ecological, economic and sociological values (Patel et al., 2008). Pomegranate origin is believed to be in Central Asia, but as its tree is adaptable to a wide array of soils and climates, it is cultivated in many areas including the Mediterranean basin, Asia and California (Holland et al., 2009).

Although the genus Punica was previously placed in its own monogenetic family Punicaceae (Graham and Graham, 2014), according to recent morphological and molecular evidences (Berger et al., 2016), as well as the new classification in the APG IV system (Byng et al., 2016), it has been suggested that it is a member of Lythraceae. Over the last few years, commercial farming has been growing gradually because of such optimistic studies on the health benefits of pomegranate. It has several ecotypes known locally as cultivars which are clonally propagated by cuttings and are selected primarily by farmers for their fruit quality (Levin, 1995; Mars, 1996).

It displays a high diversity of pomological characteristics, including fruit color, toughness of the seeds, sweetness, acidity, etc. under various environmental circumstances. Mars and Marrakchi (1999) noted that fruit morphological characteristics are useful for pomegranate identification but, because of ambiguous descriptions or 
environmental modification, morphological properties are often not clearly distinguished between cultivars (Kumar, 1999). However, it remains difficult and time-consuming to classify many cultivars through these characteristics. Cultivars must be correctly defined in order to protect the interests and rights of plant breeders. The use of molecular markers represents an efficient way of recognizing and distinguishing different genotypes of pomegranates with no environmental effects.

The advent of DNA marker technology had led to the development of many specific DNA marker systems, such as RFLP, RAPD, AFLP, SSR etc. which have been extensively employed for fingerprinting and genetic characterization of many organisms including economically important plants. AFLP (Amplification Fragment Length Polymorphism) is a DNA fingerprinting technique, first described by Vos et al. (1995). It is based on selective PCR amplification of DNA restriction fragments under stringent conditions having the potential to generate many polymorphic loci (Powell et al., 1996). Comparative studies indicated that AFLP is a powerful tool to detect levels of genetic diversity and the genetic structure of natural populations in many plant species. AFLP has been successfully used to study genetic diversity in a wide range of fruit species such as in apple (Goulao et al., 2001), date palms (Jubrael et al., 2005) or apricot (Krichen et al., 2006). In pomegranate species, several DNA based markers such as RFLP, AFLP, RAPD and SSR, have been used for genetic analysis, to detect and to classify pomegranate varieties (Jbir et al., 2008; Rahimi et al., 2006; Yuan et al., 2007; Melgarejo et al., 2009; Sinjare et al., 2016; Hasnaoui et al., 2010b; Narzary et al., 2009; Talebi et al., 2003; Zamani et al., 2007; Curro et al., 2010; Sinjare, 2015).

In this analysis, DNA polymorphisms and genetic relationships between pomegranate genotypes cultivated in Duhok province, KRG - Iraq, were investigated using AFLP markers. This is the first study of the genetic diversity between populations of pomegranates in this region.

\section{Materials and Methods \\ Plant materials}

Fifteen different cultivars of pomegranate were selected for this study from Duhok province Kurdistan region-Iraq. These cultivars belonged to four main populations grown in the different geographic and mountainous regions of the Province as shown in Table 1 and Figure 1. The first population Amedi region represented by 4 cultivars, the second population was from Duhok center and involved six cultivars, the third population represented South of Duhok province where four cultivars were collected and one cultivar from the last population in Akre region.

\section{Genomic DNA extraction}

The genomic DNA was extracted following the steps of Weigand et al. (1993), with few modifications. First, $3 \mathrm{~g}$ of fresh and young pomegranate leaves were collected from around Duhok province (Tab. 1 and Fig. 1), then ground in liquid nitrogen. The fine powder was dissolved in a preheated $\left(60^{\circ} \mathrm{C}\right) 2 \mathrm{x}$ CTAB extraction buffer $(2 \mathrm{x}$ CTAB, $5 \mathrm{M} \mathrm{NaCl}, 1 \mathrm{M}$ Tris-HCl, $0.5 \mathrm{M}$ EDTA), and incubate at $60^{\circ} \mathrm{C}$ in shaking water bath for $30 \mathrm{~min}$. The mixture was extracted with an equal volume of chloroform/isoamyl alcohol (24:1 v/v). The mixture was then centrifuged (at $1792 \mathrm{xg}$ for $30 \mathrm{~min}$ ). The aqueous phase was transferred into another tube and precipitated with 0.66 volume of isopropanol. Precipitated nucleic acids were then dissolved in TE-buffer and stored at $-20^{\circ} \mathrm{C}$ until use.

\section{AFLP assays}

Details of AFLP assay, adaptor and primer sequences, PCR conditions for permselective and selective amplifications were performed according to Vos et al. (1995) with minor modifications as follows; 250ng of DNA was double digested with $5 \mathrm{U}$ each of the two restriction enzymes, Tru 91 and Pst I in a final assay volume of $30 \mu \mathrm{l}$ containing $1 \mathrm{x}$ one-phor-all buffer $(50 \mathrm{mM}$ potassium acetate, $10 \mathrm{mM}$ Tris-acetate, $\mathrm{pH} 7.5,10 \mathrm{mM}$ magnesium acetate, pH 7.5) (Pharmacia Biotech, Uppsala, Sweden) at $37^{\circ} \mathrm{C}$ for three hours. The Pst I and Tru 91 adapters where ligated onto double digested DNA fragments by adding $50 \mathrm{pmol}$ of Tru 91-adapter, 5Upmol Pst I-adapter in a reaction containing $1 \mathrm{U}$ of T4-DNA ligase, $1 \mathrm{mM}$ rATP and $1 \mathrm{x}$ of one-phor-all buffer and incubating for $3 \mathrm{hrs}$ at $37^{\circ} \mathrm{C}$. After ligation, the reaction mixture was diluted to 1:5 using sterile distilled water. Preselective PCR amplification was performed in a reaction volume of $20 \mu \mathrm{l}$ containing $50 \mathrm{ng}$ of each of the primers (P00, M00) corresponding to the Tru 91 and Pst I adapters, $2 \mu \mathrm{l}$ of template-DNA, $1 \mathrm{U}$ Taq DNA polymerase, $1 x$ PCR buffer and $5 \mathrm{mM}$ dNTPs. PCR amplification was performed in ABI Applied Biosystems PCR System 2720 Thermocycler using 
Table 1. List of pomegranate accession from four populations

\begin{tabular}{|c|c|c|c|c|c|c|}
\hline $\begin{array}{c}\text { Cultivar } \\
\text { label }\end{array}$ & Cultivar name & $\begin{array}{c}\text { Population } \\
\text { (origin) }\end{array}$ & Taste & Peel color & Aril color & Coordinates \\
\hline $\mathrm{C} 1$ & Mlese & Amedi & Sweet-sour & Red & Red & $\begin{array}{l}37^{\circ} 05^{\prime} 24.7^{\prime \prime} \mathrm{N} \\
43^{\circ} 29^{\prime} 00.9^{\prime \prime} \mathrm{E}\end{array}$ \\
\hline $\mathrm{C} 2$ & Trshi Na Galak & Amedi & Mild sour & Red & White & $\begin{array}{l}37^{\circ} 05^{\prime} 24.7^{\prime \prime} \mathrm{N} \\
43^{\circ} 29^{\prime} 00.9^{\prime \prime} \mathrm{E}\end{array}$ \\
\hline C3 & Mlese Dindic Spee & Amedi & Sweet-sour & White & White & $\begin{array}{l}37^{\circ} 05^{\prime} 24.7^{\prime \prime} \mathrm{N} \\
43^{\circ} 29^{\prime} 00.9^{\prime \prime} \mathrm{E}\end{array}$ \\
\hline $\mathrm{C} 4$ & Dindic Ger Shreen & Amedi & Sweet & White & Pink & $\begin{array}{l}37^{\circ} 05^{\prime} 24.7^{\prime \prime} \mathrm{N} \\
43^{\circ} 29^{\prime} 00.9^{\prime \prime} \mathrm{E}\end{array}$ \\
\hline C5 & Msafik & Duhok & Sweet & White & Red & $\begin{array}{l}36^{\circ} 51^{\prime} 30.5^{\prime \prime} \mathrm{N} \\
42^{\circ} 56^{\prime} 15.0^{\prime \prime} \mathrm{E}\end{array}$ \\
\hline C6 & Mlese Duhoki & Duhok & Sweet-sour & Red & Red & $\begin{array}{l}36^{\circ} 51^{\prime} 30.5^{\prime \prime} \mathrm{N} \\
42^{\circ} 56^{\prime} 15.0^{\prime \prime} \mathrm{E}\end{array}$ \\
\hline $\mathrm{C} 7$ & Melse Sharman & Duhok & Sweet-sour & White & White & $\begin{array}{l}36^{\circ} 51^{\prime} 30.5^{\prime \prime} \mathrm{N} \\
42^{\circ} 56^{\prime} 15.0^{\prime \prime} \mathrm{E}\end{array}$ \\
\hline $\mathrm{C} 8$ & Radisho & Duhok & Mild sour & Light green & White & $\begin{array}{l}36^{\circ} 51^{\prime} 30.5^{\prime \prime} \mathrm{N} \\
42^{\circ} 56^{\prime} 15.0^{\prime \prime} \mathrm{E}\end{array}$ \\
\hline C9 & Roman Zena & Duhok & Sour & Red & Red & $\begin{array}{l}36^{\circ} 51^{\prime} 30.5^{\prime \prime} \mathrm{N} \\
42^{\circ} 56^{\prime} 15.0^{\prime \prime} \mathrm{E}\end{array}$ \\
\hline C10 & Rawa Duhok & Duhok & Sweet & White pinkish & White & $\begin{array}{l}36^{\circ} 52^{\prime} 23.9^{\prime \prime} \mathrm{N} \\
42^{\circ} 59^{\prime} 13.6^{\prime \prime} \mathrm{E}\end{array}$ \\
\hline C11 & Duhoki & South of Duhok & Sweet-sour & Pink & White & $\begin{array}{l}36^{\circ} 22^{\prime} 04.0^{\prime \prime} \mathrm{N} \\
43^{\circ} 10^{\prime} 33.8^{\prime \prime} \mathrm{E}\end{array}$ \\
\hline C12 & Rawa & South of Duhok & Sweet & White pinkish & White & $\begin{array}{l}36^{\circ} 22^{\prime} 04.0^{\prime \prime} \mathrm{N} \\
43^{\circ} 10^{\prime} 33.8^{\prime \prime} \mathrm{E}\end{array}$ \\
\hline C13 & Sin Aljamal & South of Duhok & Sweet-sour & White & Pink & $\begin{array}{l}36^{\circ} 22^{\prime} 04.0^{\prime \prime} \mathrm{N} \\
43^{\circ} 10^{\prime} 33.8^{\prime \prime} \mathrm{E}\end{array}$ \\
\hline C14 & Musabiq & South of Duhok & Sour & Red & Pink & $\begin{array}{l}36^{\circ} 22^{\prime} 04.0^{\prime \prime} \mathrm{N} \\
43^{\circ} 10^{\prime} 33.8^{\prime \prime} \mathrm{E}\end{array}$ \\
\hline C15 & Shahraban & Akre & Sweet-sour & $\begin{array}{c}\text { Green } \\
\text { yellowish }\end{array}$ & Red & $\begin{array}{l}36^{\circ} 44^{\prime} 10.0^{\prime \prime} \mathrm{N} \\
43^{\circ} 52^{\prime} 28.6^{\prime \prime} \mathrm{E}\end{array}$ \\
\hline
\end{tabular}

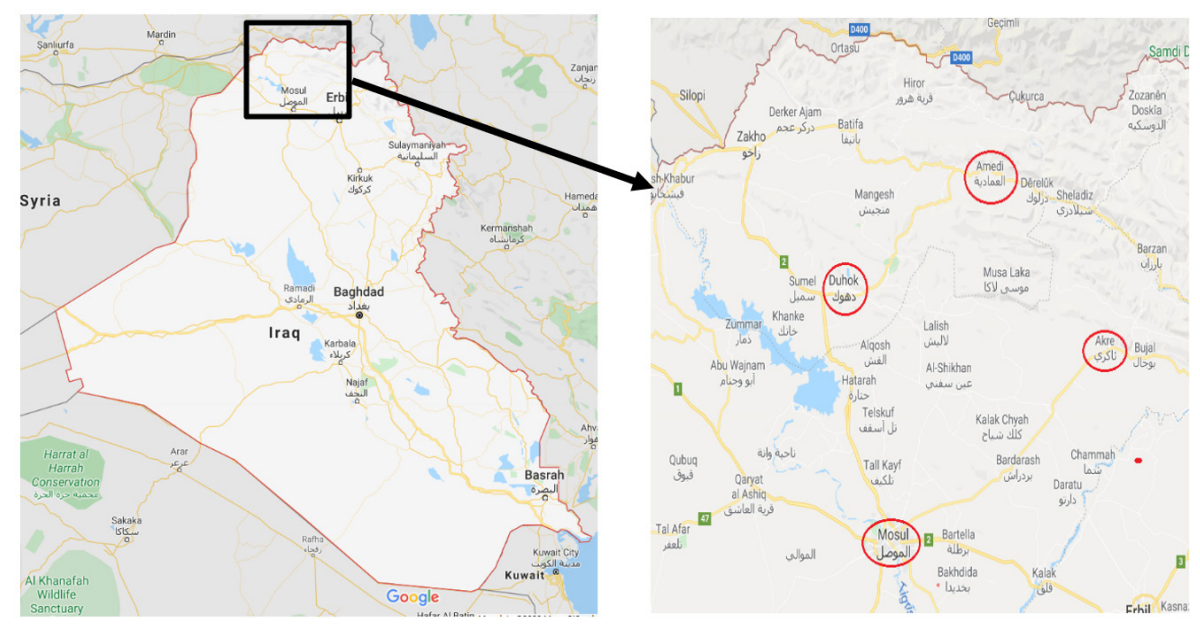

Figure 1. Geographic locations of the different pomegranate populations in the Duhok province 
the following program: 30 cycles of 30 s at $94^{\circ} \mathrm{C}$, $1 \mathrm{~min}$ at $60^{\circ} \mathrm{C}, 1 \mathrm{~min}$ at $72^{\circ} \mathrm{C}$. Pre-amplification products were then diluted to $1: 5$ and $2 \mu$ l were used as template for selective amplification. Selective amplification was conducted using Tru91 and Pst1 selective primer combinations (Tab. 2). Amplification was performed using a selective program of 36 cycles with the following profile: a $30 \mathrm{sec}$. DNA denaturation step at $94^{\circ} \mathrm{C}, 30 \mathrm{sec}$. annealing step, and a $1 \mathrm{~min}$ extension step at $72^{\circ} \mathrm{C}$. The annealing temperature in this program varied in the first cycle where it was $65^{\circ} \mathrm{C}$ and in each subsequent cycle for the next 12 cycles it was reduced by $0.7^{\circ} \mathrm{C}$ (touchdown PCR). Then for the remaining 23 cycles, it was $56^{\circ} \mathrm{C}$.

Selective amplification products were loaded onto 8\% denaturing polyacrylamide gels, and DNA fragments were staining with a silver staining kit (Promega, Madison) as manufacturer's recommendations. Silver stained gels were scanned to capture digital images of the gels after air drying.

\section{Data analysis}

In accordance with their presence (1) or absence (0), AFLP fragments were manually scored as a raw data matrix. The statistical analysis was performed by using version 2.02 of NTSYS software (Rohlf, 1998). Discriminatory power of AFLP marker could be evaluated by means of three parameters. First, Polymorphic information content (PIC), which was calculated using the formula PIC $=1-\Sigma \mathrm{pi}^{2}$, where pi is the frequency of the ith allele (Roldan-Ruiz et al., 2000). Second, Resolving power ( $\mathrm{Rp}$ ) which is the ability of each primer to detect level of variation between individuals was calculated according to Prevost and Wilkinson (1999): $\mathrm{Rp}=\Sigma \mathrm{Ib}$ where Ib (band informativeness) takes the values of: 1[2|0.5-p|], where $p$ is the proportion of individuals containing the band. And third, marker index (MI) for each primer was also calculated as a product of two functions - the polymorphic information content and effective multiplex ratio (EMR) (MI = PIC $\times$ EMR) (Tatikonda et al., 2009), where EMR is the average number of DNA fragments amplified or detected per genotype using a marker system is considered as multiplex ratio (n). The number of loci polymorphic in the germplasm set of interest analyzed per experiment is called effective multiplex ratio (E).

\section{Results and Discussion}

The preliminary results of testing 21 AFLP primer combinations, only 10 primer combinations were found to generate reproducible and clear polymorphic profiles in all 15 pomegranate genotypes. Therefore, the results of these primer combinations shown in Table 3 were further used in this study for genetic diversity evaluation of pomegranate cultivars in this region.

The total number of polymorphic bands scored was 374 out of the total 435 amplified fragments. Polymorphic bands ranged in size from 50 to 1200 bp with a percentage of polymorphism ranging from $40 \%$ in the P237/M100 primer combination to $100 \%$ in both P109/M293 and P100/M237

Table 2. The primers used for the pre-amplification and selective amplification of the pomegranate cultivars

\begin{tabular}{|c|c|c|c|c|}
\hline \multirow{2}{*}{$\frac{\text { No. }}{1}$} & \multicolumn{2}{|c|}{ Pre selective primer ('5-----3) } & \multicolumn{2}{|c|}{ Selective primer ('5-----3') } \\
\hline & P00 & GACTGCGTACATGCAG & P100 & GACTGCGTACATGCAGAACC \\
\hline \multirow[t]{10}{*}{2} & M00 & GATGAGTCCTGAGTAA & P174 & GACTGCGTACATGCAGCATG \\
\hline & & & P294 & GACTGCGTACATGCAGTACC \\
\hline & & & P237 & GACTGCGTACATGCAGGATA \\
\hline & & & P107 & GACTGCGTACATGCAGAATA \\
\hline & & & P109 & GACTGCGTACATGCAGAATG \\
\hline & & & M100 & GATGAGTCCTGAGTAAAACC \\
\hline & & & M293 & GATGAGTCCTGAGTAATACA \\
\hline & & & M291 & GATGAGTCCTGAGTAATAAG \\
\hline & & & M301 & GATGAGTCCTGAGTAATATA \\
\hline & & & M237 & GATGAGTCCTGAGTAAGATA \\
\hline
\end{tabular}


primer combinations, creating an overall average polymorphism of $86.64 \%$.

These results indicated that AFLP markers were efficient in genetic diversity analysis of pomegranate. They have also been found to be suitable marker in other fruit plants (Jubrael et al., 2005). This was evident in the number of markers scored in this study which was greater than those reported using RAPD markers for pomegranate cultivars in Iran (Sarkosh et al., 2006; Zamani et al., 2007) and Turky (Durgac et al., 2008), with $57.3 \%, 57.0 \%$ and $22.0 \%$, respectively. Therefore, it is noticeable that AFLP marker system is more powerful than RAPD to differentiate pomegranate genotypes. Jbir et al. (2008) registered AFLP markers of 34 pomegranate cultivars collected from 14 different locations in Tunisia and obtained $94.7 \%$ of polymorphism suggesting that the range of polymorphism was somehow close to that in our research. However, Yuan et al. (2007) observed an average of $73.26 \%$ among 85 Chinese pomegranate cultivars using eight AFLP primer combinations. Also, Ercisli et al. (2011) observed 73\% polymorphism among 19 genotypes using four primer combinations. Since the samples collected in this study came from a fairly similar area, the polymorphism rate can be comparable with the results described above. This abundance of genetic diversity may be the result of long-term evolution and reflects a single species evolutionary ability to respond to complex environmental changes Yuan et al. (2007).

The ability of primers (Resolving power values) to differentiate pomegranate genotypes were determined and found to be ranged from 30.40 (P109/M293) to 73.33 (P237/M100) with an average of 45.663. The PIC value was also used to estimate the discriminating power of a locus by taking into account, not only the number of alleles that are expressed but also the relative frequencies of those alleles. The PIC values ranged between ( 0.0561 to 0.4184 ) with an average of 0.297 (Tab. 3). PIC values are dependent on the genetic diversity of the genotypes chosen (Manimekalai and Nagarajan, 2006). EMR values determined ranged between 15.2 to 32.96 with an average of 24.01, while MI values calculated produced an average of 6.872 in interval of 0.964 to 10.382 . The range of the similarity matrix by the Dice coefficient was also determined and found to vary between 0.374 and 0.903 (Tab. 3).

The genetic relationship between the 15 pomegranate tested cultivars based on the Dice's similarity coefficient is shown in Table 4 and in the dendrogram (Fig. 2).

The genotypes Roman Zena from Duhok and Rawa from Duhok showed the highest genetic similarity (Jaccard's similarity coefficient was

Table 3. Genetic diversity statistics for all loci including total number of AFLP bands, percentage of polymorphic bands, polymorphism information contents, resolving powers, effective multiplex ratio and marker index in the DNA fingerprinting of pomegranate genotypes from Duhok province

\begin{tabular}{cccccccc}
\hline $\begin{array}{l}\text { AFLP primer } \\
\text { combination }\end{array}$ & $\begin{array}{c}\text { Total } \\
\text { amplified } \\
\text { bands }\end{array}$ & $\begin{array}{c}\text { Poly-morphic } \\
\text { bands }\end{array}$ & $\begin{array}{c}\text { Poly- } \\
\text { morphism } \\
\%\end{array}$ & $\begin{array}{c}\text { Polymorphic } \\
\text { information } \\
\text { content (PIC) }\end{array}$ & $\begin{array}{c}\text { Resolving } \\
\text { power (RP) }\end{array}$ & $\begin{array}{c}\text { Effective } \\
\text { multiplex } \\
\text { ratio (EMR) }\end{array}$ & $\begin{array}{c}\text { Marker index } \\
\text { (MI) }\end{array}$ \\
\hline P100/M237 & 39 & 39 & 100 & 0.3810 & 41.33 & 20.66 & 7.875 \\
\hline P100/M301 & 61 & 60 & 98.36 & 0.3149 & 40.66 & 32.96 & 10.38 \\
\hline P100/M100 & 45 & 33 & 73.33 & 0.4184 & 36.00 & 21.12 & 8.841 \\
\hline P100/M291 & 37 & 31 & 83 & 0.2743 & 57.46 & 24.07 & 6.604 \\
\hline P107/M293 & 43 & 40 & 93 & 0.3029 & 36.8 & 19.90 & 6.030 \\
\hline P109/M237 & 46 & 44 & 95 & 0.2953 & 34.93 & 20.96 & 6.193 \\
\hline P109/M293 & 26 & 26 & 100 & 0.3206 & 30.40 & 15.20 & 4.874 \\
\hline P174/M100 & 48 & 45 & 93.75 & 0.2891 & 51.46 & 30.68 & 8.872 \\
\hline P237/M237 & 40 & 36 & 90 & 0.3209 & 54.26 & 25.20 & 8.087 \\
\hline P237/M100 & 50 & 20 & 40 & 0.0561 & 73.33 & 17.17 & 0.964 \\
\hline Mean & 43.5 & 37.4 & 86.64 & 0.2974 & 45.66 & 22.79 & 6.872 \\
\hline Total & 435 & 374 & & 2.9740 & 456.6 & 227.9 & 68.72 \\
\hline
\end{tabular}




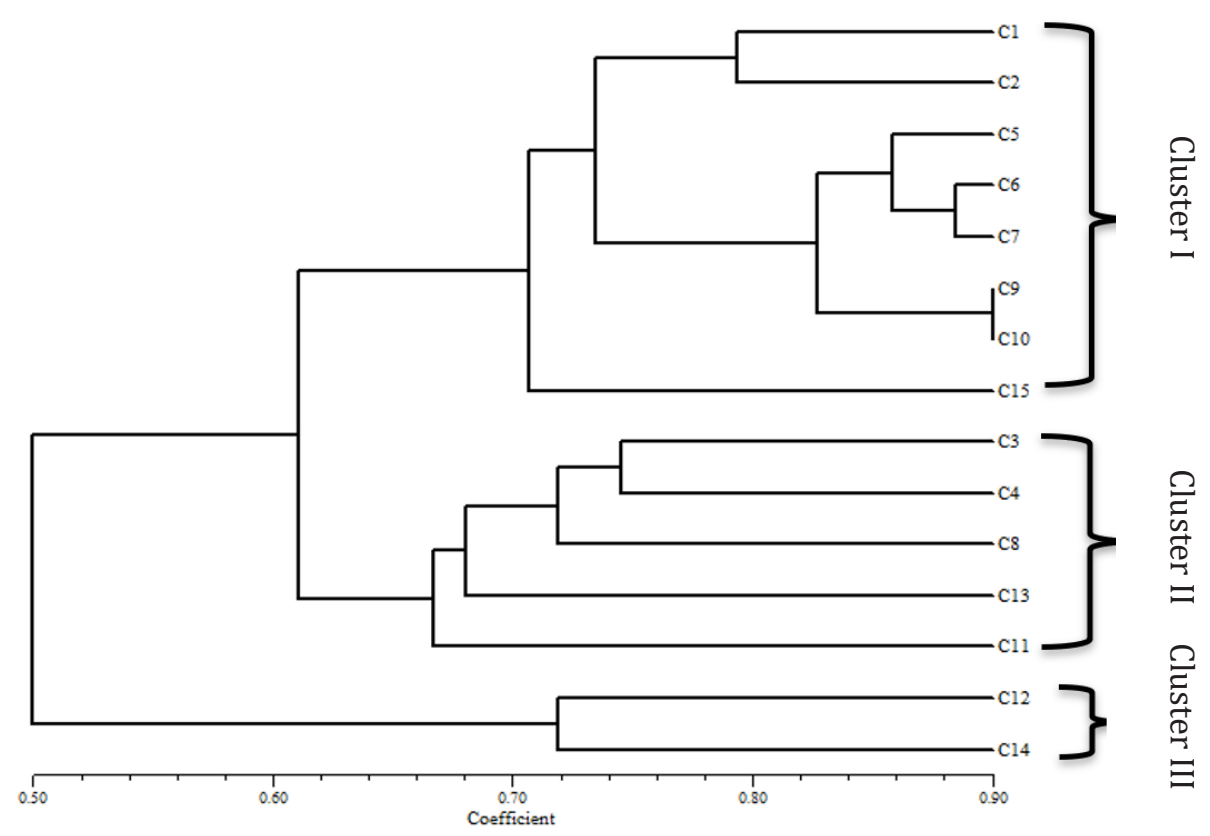

Figure 2. Dendrogram of 15 pomegranate genotypes resulting from the unweighted pair-group method of arithmetic average cluster analysis based on Jaccard's similarity coefficient obtained from 435 AFLP markers

equal to 0.9033 ) whereas their genetic variation was the lowest, and the lowest similarity was detected in Rawa from Duhok and Rawa from Mosel (Jaccard's similarity coefficient 0.3743) indicated that these two genotypes are highly distinct from the others.

According to Dice's similarity matrix and the UPGMA clustering method, the dendrogram exhibited three main clusters that were identified at the 0.9033 similarity level. Cluster 1 which include the cultivars that share the maximum similarity distance, this cluster consist of two subgroups, first subgroup containing the cultivar 1 and 2 that was identified at the 0.796 similarity level and the second subgroup including cultivars $(5,6,7,9,10$ and cultivar 15$)$ with similarity level interval of 0.9033 to 0.7047 and showed some morphological relationship. Cluster 2 contained cultivars $(3,4,8,13$, and cultivar 11$)$ grouping was from different geographical region which indicated that genetic differentiation among populations was low. Cluster 3 includes two cultivars (12 and 14) which were identified at the 0.7205 similarity level. According to the dendrogram (Fig. 2) and similarity matrix (Tab. 4), a relatively high genetic diversity was observed among the studied cultivars.
Sarkhosh et al. (2006) have also reported 0.29-0.89 similarity coefficient using RAPD markers. This indicated that there is a considerable genetic variation in the genotypes, also indicating that there is a good fit between the dendrogram clusters and the similarity matrix. In this analysis, the dendrograms of the AFLP markers did not comply with the local name and geographical origin. In fact, the findings of this analysis were correlated with those of other authors (Jabir et al., 2008; Narzary et al., 2009; Yuan et al., 2007), showing that the cultivars clustering is not geographically related. The significant amount of phenotypical variations between pomegranate genotypes such as fruit color, weight or seed hardiness etc. may be the result of environmental conditions that greatly influence quantitative characteristics. In comparison to morphological data, it was reported by Jbir et al. (2008) that molecular markers offer more reliable results in pomegranate classification. Moreover, Zamani et al. (2007) stated that in pomegranate there is a weak relationship between fruit characteristics and RAPD data and found a correlation coefficient of only $23 \%$ between morphological and RAPD data. They further suggested that various marker systems, such as SSRs and AFLPs could be used to display genetic variation between closely asso- 


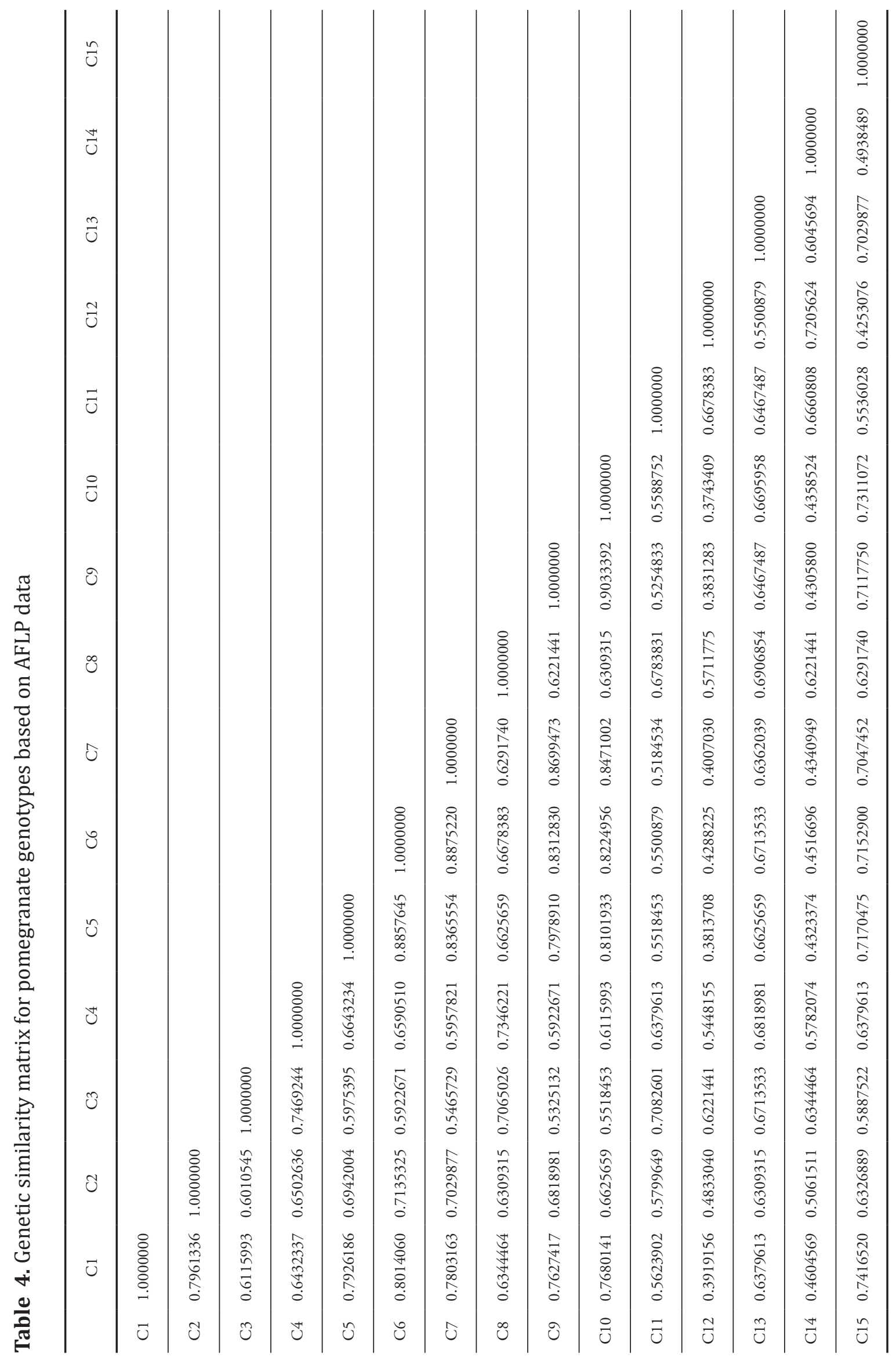


ciated pomegranate genotypes. Indeed, Mars (2001) claimed that the selection of farmers for development of pomegranate genotypes is focused primarily on fruit characteristics. Consequently, the scientific selection by farmers requires only a small part of the genome encoding these characteristics.

The clonal propagation of pomegranate in Kurdistan-Iraq and the extensive gene flow that mainly relies on gravity and small animals to disperse seeds, which makes long-distance dispersal of seeds possible between populations this may have caused a high level of genetic diversity within populations and in the same time causing low population differentiation. The genetic variation and distribution have significant impacts on life form and breeding system (Hamrick and Godt, 1996).

\section{Conclusion}

The results of AFLP markers obtained in this study performed for the first time in this region, revealed high degree of polymorphisms in pomegranate populations. The efficiency of AFLP was also evident in the detection of polymorphism between different and within populations. Thus, suggested their importance in genetic diversity analysis of pomegranate. AFLP markers may, therefore, help in pomegranate germplasm management, conservation and in future breeding programs in this region.

\section{References}

1. Berger BA, Kriebel R, Spalink D, Sytsma KJ (2016) Divergence times, historical biogeography, and shifts in speciation rates of Myrtales. Mol. Phylogen.Evol. 95: 116136.

2. Byng JW, Chase MW, Christenhusz MJM, Fay MF, Judd WS, Mabberley DJ, Sennikov AN (2016). An update of the angiosperm phylogeny group classification for the orders and families of flowering plants: APG IV. Bot. J.Linn.Soc. 181: 1-20.

3. Currò S, Caruso M, Distefano G. Gentile A, La Malfa S (2010). New microsatellite loci for pomegranate Punica granatum (Lythraceae). American Journal of Botany, 97(7): 58-60.
4. Durgac C, Ozgen M, Simsek O, Kacar Y, Kiyga Y, Celebi S, Gunduz K, Serce S (2008). Molecular and pomological diversity among pomegranate (Punica granatum L.) cultivars in Eastern Mediterranean region of Turkey. Afr J Biotech 7: 1294-1301.

5. ErcisliS, Kafkas E, Orhan E(2011). Genetic characterization of pomegranate (Punica granatum L) genotypes by AFLP markers. Biol Res. 44(4):345-50.

6. Goulao L, Cabrita L, Oliveira CM, Leitao JM (2001). Comparing RAPD and AFLP analysis in discrimination and estimation of genetic similarities among apple (Malus domestica Borkh.) cultivars. RAPD and AFLP analysis of apples. Euphytica 119: 259-270.

7. Graham SA, Graham A (2014). Ovary, fruit, and seed morphology of the Lythraceae. Int. J. Plant Sci. 175: 202240.

8. Hamrick JL, Godt MJW (1996). Effects of life history traits on genetic diversity in plant species. Phil. Trans. R. Soc. Lond.B, 351: 1291-1298.

9. Hasnaoui N, Mars M, Chibani J, Trifi M (2010). Molecular Polymorphisms in Tunisian Pomegranate (Punica granatum L.) as Revealed by RAPD Fingerprints. Diversity, 2(1): 107-114.

10. Holland D, Habit K, Bar-Ya'akov I (2009). Pomegranate: botany, horticulture, breeding. Hortic.Rev. 35:127-191.

11. Jbir R, Hasnaoui N, Mars M, Marrakchi M, Trifi M (2008). Characterization of Tunisian pomegranate (Punica granatum L.) cultivars using amplified fragment length polymorphism analysis. Scientia Horticulturae, 115(3): 231-237.

12. Jubrael JMS, Udupa SM, Baum M (2005). Assessment of AFLP-based genetic relationships among date palm (Phoenix dactylifera L.) varieties of Iraq. Journal of the American Society for Horticultural Sci. 130(3): 442-447.

13. Krichen L, Trifi-Farah N, Marrakchi M (2006). Variability, organisation and identification of Tunisian apricot (Prunus armeniaca L.) cultivars using AFLP markers. Acta Hort. 717: 251-254.

14. Kumar LS (1999). DNA markers in plant improvement. Biotechnol Adv 17: 143-183.

15. Levin GM (1995). Aspects of pomegranate culture in Turkmenistan. Plant. Genet. Resour. Newsl. 102: 29-31.

16. Manimekalai R, Nagarajan P (2006) Interrelationships among coconut (Cocos nucifera L.) accessions using RAPD markers. Genet. Resour. Crop. Evol. 53: 1137-1144.

17. Mars M (1996). Pomegranate genetic resources in the Mediterranean region. In: First MESFIN Plant Genetic Resource Meeting, Tenerife, Spain, October 2-5, 1995, pp. 345-354. 